\title{
Effect of Fermentation and Malting on Some Cereal Weaning Foods Enriched with African Locust Beans
}

\author{
${ }^{* 1}$ MOHAMMED, SSD; ${ }^{2}$ ORUKOTAN, AA; ${ }^{3}$ MUSA, J \\ 1, 2 \& 3 Department of Microbiology, Faculty of Science, Kaduna State University, Kaduna \\ *Corresponding Author: mosada78@yahoo.com or mohammed.sambo@kasu.edu.ng, Tel:+234(0)8035861774
}

\begin{abstract}
Effect of fermentation and malting on some cereal weaning foods enriched with African locust beans were carried out. Cereals (wheat and millet) were malted for the period of 144 hours and further fermented for 48 hours by natural fermentation. The millet, wheat and locust bean flours were mixed together in the ratio 70:70:40 (w/w) to produce fortified fermented-malted food .The same ratio were used in the formulation of unmalted /unfermented food and fortified products. Microbial analysis of the prepared foods were carried out using pour plate method. Physicochemical, proximate analysis were carried out using standard procedures. Nine (9) points hedonic scale were used for the sensory evaluation on the products .Bacteria such as Lactobacillus sp, Bacillus sp, Clostridium sp, Leuconostoc sp, Staphylococcus sp, Streptococcus sp, E.coli, Salmonella $\mathrm{sp}$ and fungal isolates include Aspergillu ssp, Saccharomyces sp, Candida sp, Penicillium sp, Mucor and Rhizopus sp were isolated from the fermented grains. Staphylococcus sp, E.coli, Salmonella sp and some Moulds were isolated after 24 hours of fermentation and malting of the grains. The $\mathrm{pH}$ of 3.89 in millet and 4.04 in wheat were observed during malting and fermentation processes. Total titratable acidity (TTA) of malted/fermented millet was $2.46 \%$ and wheat had $2.31 \%$ TTA. Percentage crude protein increased from $3.33 \%$ in malted/fermented blend (sample A) to $6.3 \%$ while unmalted/unfermented (sample B) and fortified product (sample C) had decrease in \% crude protein. Percentage fat content decreased from $6.17 \%$ in sample A to $5.9 \%$. The $\%$ crude carbohydrate content decrease from 80.43 in sample A to 80.15 but higher values were obtained in sample B with sample C having $80.35 \%$.Percentage moisture and ash content decreased after malting and fermentation in sample A and B except in sample C. The mean scores of sensory evaluation revealed that the formulated malted/fermented and fortified foods were liked very much compared to the unmalted/unfermented foods which are moderately and slightly liked. (C) JASEM
\end{abstract}

https://dx.doi.org/10.4314/jasem.v21i5.17

Key words: Fermentation, bacteria, malting, cereal weaning foods, moulds,

Cereals can be defined as a grain or edible seed of the grass family, Gramineae (Bender and Bender, 2009). Cereals are grown for their highly nutritious edible seeds, which are often referred to as grains. Some cereals have been staple foods both directly for human consumption and indirectly via livestock feed since the beginning of civilization (British Nutrition Foundation, BNF, 2004).

Wheat is a major cereal crop in many parts of the world. It belongs to the Triticum family, of which there are many thousands of species (Kent and Evers 2004), with $T$. aestivumsub species vulgare and the hard wheat $T$. durum being the most important commercially.

Millet refers to a number of different species, all of which are small-grained annual cereal grasses (Macrae et al., 2006). The African locust bean tree (Parkiabiglobosa) are perennial trees legumes which belongs to the sub-family mimosoideae and family leguminosae (now family fabaceae).

The African locust bean tree (Parkiabiglobosa) are perennial trees legumes which belongs to the subfamily mimosoideae and family leguminosae (now family fabaceae). They grow in the savannah region of West Africa up to the southern edge of the Sahel zone 13. A matured locust bean tree (20 -30 years) can bear about a tone and above of harvested fruits. From experience, the tree can start to bear fruits from five to seven years after planting. The most important use of African locust bean is found in its seed, which is a grain legume, although it has other food and non - food uses, especially the seeds which serves as a source of useful ingredients for consumption (Goldberg, 2003). The fruit shell traditionally is used to extract a substance that helps to harden the natively made house floors and can be an important source of tannin for leather tanning. The yellow powdery substance which our people use in our native gruel that can be taken pure or fed to pigs is known to have useful extractable products (Goldberg, 2003). The seeds, which traditionally are used as food condiment, are known to be rich in protein and contain easily digestible calcium. It's indicated that the seed in addition to be rich in protein contains $20 \%$ edible oil. Nutritionally, the locust bean is very important particularly in the third world countries where the need for protein supplementation is high for both adult and infants. The processing of locust bean fruits into food condiment undergo series of unit operations and it was observed that these unit operations are still done manually by the processors 
in Nigeria which has made the processing of locust bean seeds into food condiment to be faced with challenges (Goldberg, 2003). The health benefit of African locust beans include: it's popularly used in seasonal traditional soups and had shown promise in boosting cellular immunity in immune compromised persons, Fermented locust bean seed used in controlling diabetes and cholesterol level, It helps in the management of diarrhea and heart disease and as an antidote to snake bite, It also saves as foods supplement to malnutrition, Helps to reduce blood sugar and management of bacterial infections, Crushed bark has also been revealed in wound treatment and serves in treating leprosy (Goldberg, 2003).

Fermentation has been defined in various ways. In these contexts fermentation may yield desirable product and once the process does not yield desirable product, such nutritional improvement may not be consider fermentation. Steinkrous ( 2003),explained and defined fermented food as food substrate that are overgrown by edible microorganisms whose enzymes particularly amylases, proteases and lipases hydrolyze polysaccharide, proteinand lipid to nontoxic product with characteristics as flavor, aromas, texture, shelf-life and appearance (Steinkrous, 2003). Fermentation and malting have been shown to be the most effective and convenient for the improvement of nutritional value and reduction of bulk and viscosityof cereal foods (Ariahuet al., 2009). Fermentations may be monitored in various ways, including measuring the decrease in specific gravity of the wort (including in-process measurements), $\mathrm{CO}_{2}$ evolution , the $\mathrm{pH}$ decrease , and ethanol formation (as well as camera-based observation of events in the fermenter (.Nicholas et al.,2013).

Malting involves germination and sprouting of cereal grain. During the process the seeds is soaked in water during which the grain is rehydrated and a number of complex chemical reaction are activated (Brigas et al., 2003). Malting and fermentation can have multiple effects on the nutritional value of food (Brigas et al., 2003). This research is therefore aimed at evaluating the effect of fermentation and malting on some cereal weaning foods fortified with African locust beans.

\section{MATERIALS AND MEHODS}

Sample Collection: The grain samples of wheat (Triticuma estivum), millet (Pennisetum glaucum) and seeds from African locust bean tree (Parkia biglobosa) were collected from Institute of Agricultural Research (I.A.R) in Zaria, Kaduna State. The samples were transported to the Department of
Microbiology laboratory, Kaduna State University in a cleaned polyethylene bags for analysis. After the manual sorting and winnowing to remove stones and defective seed, the cleaned seed were packed in a container and tightly covered with a lid and then taken for processing and analysis.

Preparation of Media: The media used were prepared according to the manufacturer instructions. Twenty eight grams (28 g) of the nutrient agar (NA) powder was weighed, and $1000 \mathrm{ml}$ of distilled water was measured and transferred into clean conical flask. Thirty five $(35 \mathrm{~g})$ of saboraud dextrose agar (SDA) was also weighed and dissolved in $1000 \mathrm{ml}$ of sterile distilled water separately. A glass rod was used to stir the mixture while heating for about 1-3 minutes until it was brought to boil. The mixture was sterilized by autoclaving at $121^{\circ} \mathrm{C}$ for 15 minutes. The media were removed for further used (Ariahuet al., 2009).

Samples Preparation: Preparation of Malted Wheat and Millet. Two hundred gram (200g) of cereal grains were weighed and washed with $5 \%(\mathrm{w} / \mathrm{v})$ sodium chloride solution to suppress growth of moulds ( $\mathrm{NaCl}$ is optional). The grains were steeped in tap water at room temperature in clean container for about 24 hours. The grains were placed in container for drainage of water after which they were spread in a moist bag and allowed to sprout for 4 days at room temperature $\left(28 \pm 2{ }^{\circ} \mathrm{C}\right)$. The germinated seeds were dried with the control moisture in an air draft oven (kilning) at $75-85^{\circ} \mathrm{C}$. The testa and rootlet were detach from cotyledons during slitting and were separated by winnowing (Ariahu et al., 2009). The agar medium sets like stiff gelatin at room temperature. The agar medium was then ready for use

Preparation of Fermented and Unfermented Grains: Two hundred gram (200g) of malted millet and wheat samples were soaked in a separate plastic bucket containing $300 \mathrm{ml}$ of water and steeped for 48 hours at room temperature $\left(28 \pm 2^{\circ} \mathrm{C}\right)$. The steeped water was discarded by decantation and the fermented grains were oven dried at $50^{\circ} \mathrm{C}$ for 2 days to reduce the moisture content. The fermented and unfermented grains were milled using Kenwood blender to a smaller particle size of less than $0.3 \mathrm{~mm}$ separately. The milled grains were sieved through a fine mesh sieve to obtain fermented and unfermented grains flour and used for analysis (Mbata et al., 2009; Ariahu et al., 2009.

Locust Beans Flour Processing: One hundred and fifty gram $(150 \mathrm{~g})$ of cleaned locust beans was soaked in $200 \mathrm{ml}$ of water for 1 hour and then boiled for 2 
hours; it was then cooled overnight. The locust beans was then washed to remove cover, dried for 48 hours and roasted in an oven at $85^{\circ} \mathrm{C}$ for 30 minutes, these was to reduce the beny flavor. The roasted locust beans was allowed to cooled then milled using Kenwood blender to an average particle size of about $0.2 \mathrm{~mm}$ and it was sieved through a fine mesh to obtain the locust beans flour (Mbata et al., 2009).

Formulation of Fermented-Malted Cereals and Legumes Mixed: After the preparation of the samples, the millet, wheat and locust bean flours were mixed together in the ratio 70:70:40 (w/w) $40 \mathrm{~g}$ of locust bean flour was mixed with $70 \mathrm{~g}$ of millet and wheat flour to produce fortified fermented-malted food. The same ratio was also used in the formulation of unmalted/unfermented food product.

Microbiological Analysis of Samples: The total bacteria count was carried out using standard microbiological technique. Nutrient agar (NA) generally enhanced the growth of bacteria by providing favorable condition. Pour plate method was used as described by Olutiola et al.(2000); Adegoke, (2004); Prescott et al.(2005); the samples were first serially diluted to 5 fold dilution. One $\mathrm{ml}(1 \mathrm{ml})$ of each grains slurry sample were taken at 0hour, 24 hours, 48hours, 72 hours, 96 hours and 144 hours at different malting period and $0 \mathrm{hr}, 24 \mathrm{hrs}$ and $48 \mathrm{hrs}$ during fermentation period respectively and transferred into a $9 \mathrm{ml}$ sterile distilled water and were thoroughly mixed aseptically to give a dilution of factor $10^{-1}$. Subsequent serial dilutions were made to get the dilution factors of $10^{-2}, 10^{-3}, 10^{-4}$ and $10^{-5} .1 \mathrm{ml}$ of appropriate dilution was used to inoculate each of the plates in duplicate. The culture plates were incubated at $37^{\circ} \mathrm{C}$ for 24 hours. After 24 hours of incubation, the colonies in each plate were counted using the colony counter.

Bacteria load $(\mathrm{cfu} / \mathrm{ml})=\mathrm{N} \times 1 / \mathrm{v} \times \mathrm{D}$ Where: $\mathrm{N}=$ Number of colonies counted; $\mathrm{V}=$ Volume of inoculums; $\mathrm{D}=$ Dilution factors (Adelekan et al., 2013)

Discrete bacteria colonies in culture plates were selected using sterilized wire loop and sub-cultured from the mixed cultures on freshly prepared agar plates and were incubated at $37^{\circ} \mathrm{C}$ for 24 hours. The discrete colonies were further sub cultured on agar slants and were incubated at $37^{\circ} \mathrm{C}$ for another 24 hours for each isolate respectively (Adelekan et al., 2013).

Characterization and Identification of Bacteria Isolates: The biochemical tests of each isolate were carried out using standard methods as described by Cheesbrough (2009). The biochemical tests include: Gram's staining, catalase test, coagulase test, indole test, motility test, urease test and triple sugar iron test.

Isolation of Moulds and Yeasts: The mould and yeast strains were isolated in pure culture using sabouraud dextrose agar (S.D.A.). The selected discrete colonies were picked, streaked by using a sterile wire loop onto the surface of freshly prepared sabouraud dextrose agar medium and were incubated at room temperature for $\left(22-25^{\circ} \mathrm{C}\right)$ for 3 days.

Determination of Mould Counts: This was done on Saboraud Dextrose Agar (SDA) using pour plate method as described by Harrigan (2005). One milliliter $(1 \mathrm{ml})$ of the dilution was dispensed into sterile plate and $20 \mathrm{ml}$ sterilized Sabouraud Dextrose Agar at $45^{\circ} \mathrm{C}$ was added and the plates were rocked to have even spray of the sample with the medium for each sample respectively. The plates were incubated at room temperature $\left(22^{\circ}-25^{\circ} \mathrm{C}\right)$ for 3 days. After incubation period, the growth colonies on the plate were counted as colony forming unit $(\mathrm{cfu} / \mathrm{ml})$ and the result was recorded per dilution counted.

Characterization and Identification of Moulds and Yeasts: Microscopic identification of yeasts and moulds were carried out. A sterile wire loop was used to pick a small portion of colonies separately and was placed on a drop of lacto-phenol cotton blue on clean grease free slides and was cover with a cover slip. The prepared slides were viewed under the microscope using $\mathrm{x} 10$ and $\mathrm{x} 40$ objective lens to observe the spores and some filamentous structures as described by Prescott et al. (2005).

Physicochemical and Proximate Analysis of Laboratory Prepared Weaning Food: The percentage of total titratable acidity (TTA) of the samples were determined using direct titration method described by Nelson (2002) and $\mathrm{pH}$ determination was carried out using Jenway pH meter model 1305 as described by (Obadinaet al., 2008). The proximate analysis carried out include: percentage $(\%)$ moisture content ,total ash, crude fat, crude protein content and carbohydrate content, (AOAC, 2005).

Sensory Evaluation of Fortified Malted-Fermented and Unmalted-Unfermented Cereals and Legume: The sensory characteristics of the fortified maltedfermented and unmalted-unfermented cereals and legume dough products were assessed by 10 and 10 Under Graduate Students from Microbiology 
Department, Kaduna State University to evaluate the appearance, colour, texture, flavor, taste and overall acceptability of the products. The samples were served with disposable cups for each person to drink the prepared weaning foods. The panelists were instructed to sip water before and after assessing each product. The judges recorded sensory characteristics of each sample using 9-point hedonic scale as described by Fapounda and Adeware (2012). Scoring with 9 being like extremely, 8 being like very much, 7 being like moderately, 6 being like slightly, 5 being neither like nor dislike, 4 being dislike slightly, 3 being dislike moderately, 2 being dislike very much and 1 being dislike extremely.

\section{RESULTS AND DISCUSSION}

The results in figure 1 revealed the mean total aerobic counts of bacteria and moulds during the malting periods. The wheat sample had the highest mean total aerobic count of $1.08 \times 10^{4} \mathrm{cfu} / \mathrm{ml}$ while the lowest total aerobic count was $2.10 \times 10^{3} \mathrm{cfu} / \mathrm{ml}$. During the malting, the highest mean mould counts was also recorded as $1.00 \times 10^{4} \mathrm{cfu} / \mathrm{ml}$ while the lowest mould count was $3.00 \times 10^{4} \mathrm{cfu} / \mathrm{ml}$. The total aerobic counts and mean mould counts of millet sample during malting period was also recorded, with the highest mean total aerobic count of $1.88 \times 10^{3} \mathrm{cfu} / \mathrm{ml}$ while the lowest total aerobic count was $1.20 \times 10^{4} \mathrm{cfu} / \mathrm{ml}$. Mean mould count was also recorded with $5.6 \mathrm{x}$ $10^{2} \mathrm{cfu} / \mathrm{ml}$ as highest total aerobic counts, while the lowest mould count is $2.00 \times 10^{2} \mathrm{cfu} / \mathrm{ml}$ respectively. Figure 2 also indicated the mean total bacteria and mould counts at different fermentation period of wheat and millet samples. The wheat sample had the highest mean total aerobic count of $5.2 \times 10^{3} \mathrm{cfu} / \mathrm{ml}$, while the lowest total aerobic count is $3.8 \mathrm{x}$ $10^{3} \mathrm{cfu} / \mathrm{ml}$. Mean mould counts was also recorded with highest mould count of $8.1 \times 10^{4} \mathrm{cfu} / \mathrm{ml}$, while the lowest mould count is $5.1 \times 10^{4} \mathrm{cfu} / \mathrm{ml}$. The millet sample had the highest mean total aerobic count of $8.8 \times 10^{3} \mathrm{cfu} / \mathrm{ml}$, while the lowest total aerobic count is $2.4 \times 10^{3} \mathrm{cfu} / \mathrm{ml}$. The highest mean mould count was also recorded as $1.00 \times 10^{4} \mathrm{cfu} / \mathrm{ml}$, while the lowest mould count was $1.6 \times 10^{4} \mathrm{cfu} / \mathrm{ml}$ during the fermentation respectively. The results in figure 3 and 4 showed the $\mathrm{pH}$ and Titratable Acidity of wheat and millet at different malting and fermentation periods. While results in figure 5 showed the total bacterial and mould counts of the processed wheat and millet. There were variations in the counts. The proximate composition of unmalted/unfermented, malted/fermented wheat and millet and malted/fermented enriched product showed that the fermented mix had the best proximate values among the weaning foods prepared. And figure 6 showed the sensory evaluation of the prepared weaning foods from malted and fermented products. There were general acceptability of the prepared weaning foods from malted, fortified and the fermented products. The results in Table 1 and 2 revealed the morphological and biochemical characteristics of bacteria isolates from wheat and millet samples at different malting periods where Bacillus sp and Staphylococcus sp were the predominant bacteria isolated within 0- 144 hours and 24- 96 hours of malting period respectively. Table 3 and 4 showed the cultural, and biochemical characteristics of bacteria isolated from wheat and millet samples during the fermentation period where Lactobacillus sp was the predominant bacteria during the malting period at 24- 48 hours respectively while Table 5 and 6 revealed the cultural and morphologically structures of yeasts and moulds isolated from wheat and millet during the malting period. The predominant fungi species isolated at 0- 144 hours of malting were Aspergillus and Penicillium sp at 24- 48 hours of the malting period (Table 5 and 6). And Table 7 and 8 showed the yeasts and mould at different fermentation period where Aspergillus, Candida, Penicillum and Saccharomyces were identified during the fermentation period between 048 hours respectively. Table 9 indicate the cultural and biochemical characteristics of bacteria isolates from the processed wheat and millet samples. Lactobacillus sp was the only bacteria isolated from the processed wheat and millet samples (Tables 9). Table 10 revealed the cultural and morphologically structures of yeasts and mold from processed cereals. Where fungi species such as Saccharomyces and Candida were isolated and identified (Table 10). The viable bacteria count declined from $1.08 \times 10^{4} \mathrm{cfu} / \mathrm{ml}$ to $8.0 \times 10^{3} \mathrm{cfu} / \mathrm{ml}$ in wheat and $1.88 \times 10^{4} \mathrm{cfu} / \mathrm{ml}$ to $8.80 \times 10^{3} \mathrm{cfu} / \mathrm{ml}$ in millet at the end of the steeping phase. This may be attributed to the organic acid being formed, low oxygen tension and some other toxic compound as well as low $\mathrm{pH}$ value were observed. The total mesophilic counts in wheat and millet during steeping is often regarded as the most critical step in malting with respect to microbial load, which is about 0-24 hours as reported by Noots et al. (2008) while working with wheat and barley. This is in agreement with Sullivan et al. (2000) who reported that viable numbers decreased substantially during steeping. The fungal microflora during steeping begins to proliferate, resulting in a coat of bacteria. High yeasts and mould count was recorded during steeping from $2.00 \times 10^{4}$ to $3.2 \times 10^{4} \mathrm{cfu} / \mathrm{ml}$ in millet and $3 \times 10^{4}$ to $6.8 \times 10^{4} \mathrm{cfu} / \mathrm{ml}$ in wheat, this is an indication of possible contamination of the grains during storage as reported by Petterset al. (2008) on his work on maize. During the period of germination, 
there was a rapid raised and falled in microbial count;. Bacteria constitute the dominant microflora in wheat and millet samples. These may be due to their ability to formed complex matrix in form of biofilm during grains germination as agreed by the work of Douglas and Flannigan (2009) while working on cereals. Unlike during steeping, yeasts and mould count picked up during germination. An increase in fungal count was observed during the period on both samples. The high number of colonies observed may be due to low water activities that favor their growth during germination as reported by Sullivan et al. (2000). The final process during malting influence microbial stability of the malt, the kilning temperature which is about $75-85^{\circ} \mathrm{C}$ for 24 hours as in consistence with the work of Laitila (2007) on his work on wheat. He reported that malting procedures strongly influence the microbial load of the malt. The total viable counts in the final malt and typically reduced by a factor $5.1 \times 10^{3}$ to $2.1 \times 10^{3} \mathrm{cfu} / \mathrm{ml}$ colonies in wheat and $2.02 \times 10^{4}$ to $1.20 \times 10^{4} \mathrm{cfu} / \mathrm{mlin}$ millet as compared to the start of the kilning. Certain heat-resistant bacteria may be present due to their ability to form spores as also reported by Schwarz et al. (2005) who revealed the decrease in viable count after kilning on cereals. Yeasts and mould count significantly declined in wheat and millet as compared to early hours of kilning. Their organization in biofilms and spore forming ability might explain their high resistance to heat as also reported by Raulioet al. (2009) on his work on barley and wheat. The change in $\mathrm{pH}$ and TTA value during malting period was observed, there was significant decrease in $\mathrm{pH}$ from 0 to 144 hours in millet and wheat sample with increase in TTA in both samples at different malting period respectively. Significant decrease and increase in $\mathrm{pH}$ and TTA during fermentation period was also recorded from 0 to 48hours in millet and wheat sample, with increase in TTA in millet and wheat samples as fermentation period progresses respectively. These could be as a result of the hydrolysis of some complex organic molecules such as lipids, protein and phytin which could be hydrolyzed to fatty acids, lactic acid, acetic acid, amino acids and phosphate respectively during fermentation and malting as also reported by Uvereet al. (2010) on his work on sorghum. Thus the increase in acidity and decrease in $\mathrm{pH}$ accompanying malting and fermentation period could be attributed to the extent of these complex molecules and therefore of the digestibility of malted and fermented wheat and millet. This is in agreement with the finding of Adeyemoet al. (2003) while working on maize. The proximate composition of unmalted/unfermented (sample A), malted/fermented (B) and fortified product $(\mathrm{C})$. There was slight decrease in protein content in sample B as compare to sample A. This could be as a result of metabolization of stored nitrogen in wheat and millet to aid germination. However, the significant increase in sample $\mathrm{C}$ was as a result of the compensation of the loss nitrogen with legumes that is considered to be rich in protein. This is consistent with the finding of Adeyemoet al. (2003) who reported an increase in protein content by adding legumes to cereals grains. The moisture content of sample B and C were differed significantly from each other. Low moisture content indicates their better shelf-life of the product. Moisture content in excess $14 \%$ in fermented product has greater danger of microbial spoilage as agreed by Adeyemoet al. (2003). There was slight decrease in the ash content in samples B as compare to A and C. Loss in ash may be due to leaching of soluble inorganic salt into the processing water and compensation of the leached inorganic salt in sample $\mathrm{C}$ or lactic acid bacteria used it for their metabolic activities as also reported by Osman (2007). The fat content in sample A of unmalted/unfermented product differed significantly from that of sample B and C. The decrease in fat observed could be attributed to the activities of lipolytic enzymes during malting/fermentation as in agreement with Uvereet al. (2010) who worked on beni-seed. The carbohydrate content was $80.43 \%$ for sample A, $80.15 \%$ for sample B to $81.32 \%$ in sample C. Carbohydrate decrease steadily after malting and fermentation. This is in agreement with the result of Adegbehingbe (2007) that reported decrease in carbohydrate on sorghum and maize flour. Loss in carbohydrate may be as a result of the utilization of some complex sugar by lactic acid bacteria and some yeast for growth and metabolic activities as in agreement with the work of Adegbehingbe (2007). The microorganisms isolated at different malting period were peculiar to many malted and fermented foods product. Previous studies suggested that microorganisms associated with malting of cereal grains also serve as inoculums for their natural fermentation process (Omemu, 2011). Steeping is often regarded as the most critical step in malting with respect to microbial activity and their safety as reported by Nootset al. (2008). Bacteria isolated during steeping were Escherichia coli, and Salmonella species as predominance during the steeping phase in wheat and millet samples, these enterobacteriaceae are suspected to be source from the environmental factors during storage, handlers and utensil. Lactic acid bacteria (LAB) heavily develop because of the limited oxygen availability during steeping period while others pathogenic once are eliminated due to some toxic compound being formed as agreed by Laitila et al. (2006) on his work on millet and maize. The fungal microflora is 
generally dominated by yeasts and mould that prefer growth temperatures beneath $30{ }^{\circ} \mathrm{C}$. Some fungal genera isolated at steeping phase during malting period were Aspergillus species, and Penicillium

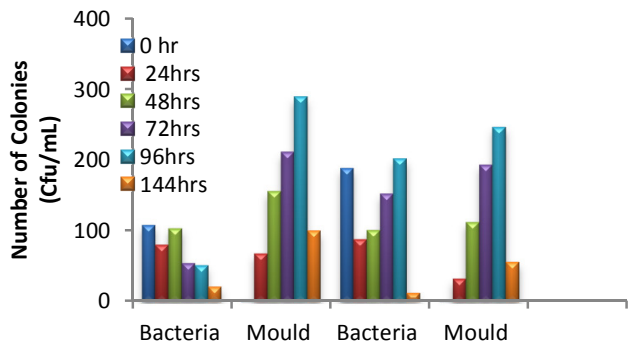

Fig 1: Mean Mesophilic Bacteria and Fungi counts of Wheat and Millet during the Malting period

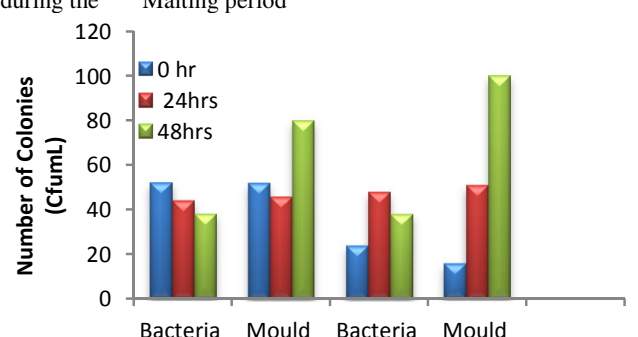

Bacteria Mould Bacteria Mould
Fig 2: Mean Mesophilic Bacteria and Fungi counts of Wheat and Millet samples at different fermentation period

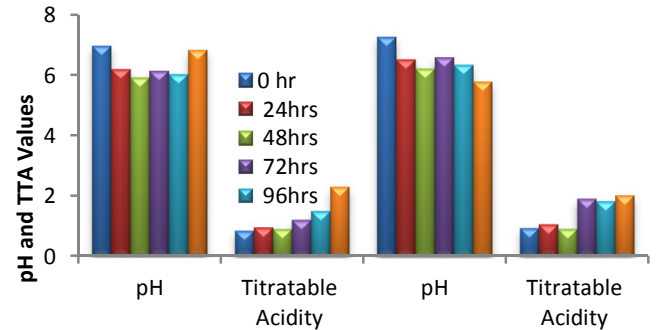

Fig 3: $\mathrm{pH}$ and Titratable Acidity of Millet and Wheat at different Malting Periods. species were found to initiate fermentation. Their source might also be from steeping water used, grains or environmental contamination as reported by Lowe and Arendt (2004) while working with cereals

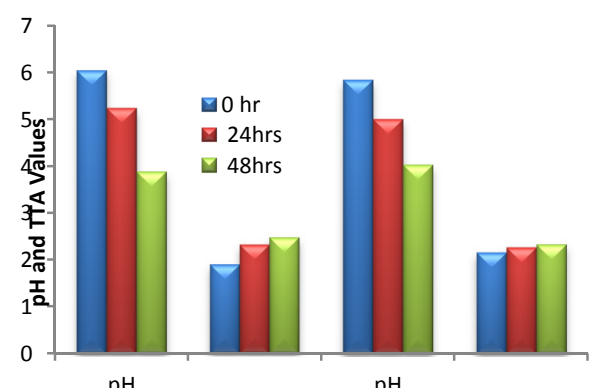

Fig 4: $\mathrm{pH}$ and Titratable Acidity of Millet and Wheat at different Fermentation Periods.

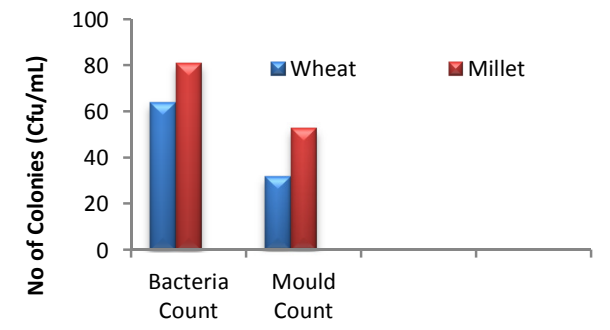

Fig 5:Total Bacterial and Mould counts of the Processed Wheat and Millet

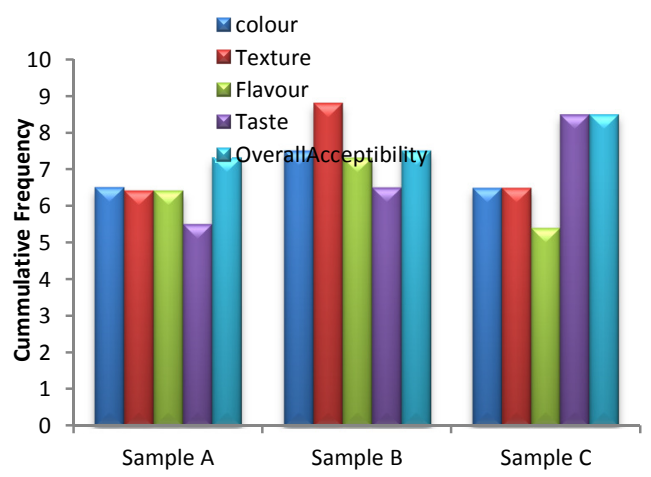

Fig 6 .Sensory Evaluation of Prepared Weaning Foods

\begin{tabular}{|c|c|c|c|c|c|c|c|c|c|}
\hline $\begin{array}{l}\text { Malting } \\
\text { period } \\
\text { (hrs) }\end{array}$ & Cultural Appearance & Gram Reaction & Catalase & Coagulase & Urease & Indole & Motility & TSI & $\begin{array}{l}\text { Probable } \\
\text { Organism }\end{array}$ \\
\hline \multirow[t]{2}{*}{0} & $\begin{array}{l}\text { Flat, circular, raised, } \\
\text { creamy colonies }\end{array}$ & $\begin{array}{l}\text { Gram -, rod chain, } \\
\text { Gram and cluster }\end{array}$ & + & + & + & + & - & $\mathrm{A} / \mathrm{G}$ & Escherichia coli \\
\hline & & & + & + & + & - & - & $\mathrm{A} / \mathrm{G}$ & Klebsiellasp \\
\hline \multirow[t]{2}{*}{24} & $\begin{array}{l}\text { Flat, creamy, big, } \\
\text { irregular, round. }\end{array}$ & $\begin{array}{l}\text { Gram+, cocci, rod, } \\
\text { chains in pairs }\end{array}$ & + & - & - & - & + & $\mathrm{A} / \mathrm{G}$ & $\begin{array}{l}\text { Streptococcus } \\
\text { sp }\end{array}$ \\
\hline & & & + & + & + & - & - & $\mathrm{A} / \mathrm{G}$ & $\begin{array}{l}\text { Staphylococcus } \\
\mathrm{sp}\end{array}$ \\
\hline \multirow[t]{2}{*}{48} & $\begin{array}{l}\text { Creamy, whitish, } \\
\text { round, } \\
\text { pinpoint }\end{array}$ & $\begin{array}{l}\text { Gram+, cocci, single in } \\
\text { chain }\end{array}$ & + & - & - & - & - & & $\begin{array}{l}\text { Streptococcus } \\
\mathrm{sp}\end{array}$ \\
\hline & & & + & - & + & - & - & $\mathrm{A} / \mathrm{G}$ & Leuconostocsp \\
\hline \multirow[t]{2}{*}{72} & $\begin{array}{l}\text { Raised, Pinpoint, } \\
\text { irregular, } \\
\text { milky colonies }\end{array}$ & $\begin{array}{l}\text { Gram+, rod, cocci, } \\
\text { some in cluster }\end{array}$ & + & - & + & + & + & $\mathrm{A} / \mathrm{G}$ & Bacillus sp \\
\hline & & & + & - & + & - & - & $\mathrm{A} / \mathrm{G}$ & Leuconostocsp \\
\hline \multirow[t]{2}{*}{96} & $\begin{array}{l}\text { Pinpoint, irregular, } \\
\text { creamy colonies }\end{array}$ & Gram+, rod in cluster & + & - & + & + & + & $\mathrm{A} / \mathrm{G}$ & Bacillus sp \\
\hline & & & + & - & + & + & - & $\mathrm{A} / \mathrm{G}$ & Lactobacillus sp \\
\hline \multirow[t]{2}{*}{144} & $\begin{array}{l}\text { Flat, pinpoint, } \\
\text { Regular colonies }\end{array}$ & $\begin{array}{l}\text { Gram+ rods, clusters in } \\
\text { pairs }\end{array}$ & + & + & + & + & - & $\mathrm{A} / \mathrm{G}$ & Bacillus sp \\
\hline & & & - & + & + & - & - & $\mathrm{A} / \mathrm{G}$ & Clostridium $\mathrm{sp}$ \\
\hline
\end{tabular}

Period. Key: + =Positive, $-=$ Negative, TSI = Triple sugar iron, A/G = Acid and Gas, sp. =species 
The major metabolic changes in the cereal grains take place during germination, including conversion of residual carbohydrates to fermentable simple sugars by amylases and proteases. In parallel, during germination which is most prolong period during malting about 3-4days (24-96 hours). Lactic acid bacteria were predominant during steeping, in these phase particularly Leuconostoc species have been found, this may due to their low $\mathrm{pH}$ tolerance. Others found are Bacillus species which is important producers of extracellular proteases which could hydrolyze complex plant proteins to amino acids and short chain peptides during germination phase. This is in consistence with Haikaraet al. (2002) who reported presence of Bacillus $\mathrm{sp}$ on sorghum. However, others genera such as staphylococcus sp were an indication of possible contamination from environment which is in consistent with Noots (2008) on same sorghum. Nevertheless, great variation in species diversity was observed between different malting periods. Unlike during steeping, yeasts have found several genera in cereals including Saccharomyces sp and Candida are dominant at the end of germination as reported by Jespersen (1994) while working with millet. For the filamentous fungi, molds isolated (Penicillium, Aspergillus, Mucor and Rhizopus). They are commonly present as contaminants in cereals. Their sources could also be from the utensils, the processing water or the environment as in agreement with the findings of Omemu (2011) who did similar work on maize. The final process during malting is crucial to microbial stability and quality of the malt. The kilning temperature is about $75-85^{\circ} \mathrm{C}$ for 24 hours at $96-144$ hours during the malting period.

\begin{tabular}{|c|c|c|c|c|c|c|c|c|c|}
\hline $\begin{array}{r}\text { Malting } \\
\text { period (hrs) }\end{array}$ & Cultural Appearance & Gram Reaction & Catalase & Coagulase & Urease & Indole & Motility & TSI & $\begin{array}{l}\text { Probable } \\
\text { Organism }\end{array}$ \\
\hline \multirow[t]{2}{*}{0} & $\begin{array}{l}\text { Raised,circular, regular } \\
\text { and milky colonies }\end{array}$ & $\begin{array}{l}\text { Gram-ve rod, } \\
\text { chain and cluster }\end{array}$ & + & + & + & + & + & $\mathrm{A} / \mathrm{G}$ & Salmonella sp \\
\hline & & & + & + & + & + & - & $\mathrm{A} / \mathrm{G}$ & Escherichia coli \\
\hline \multirow[t]{2}{*}{24} & $\begin{array}{l}\text { Smoth, big, round } \\
\text { and irregular colonies }\end{array}$ & $\begin{array}{l}\text { Gram+, cocci, rod } \\
\text { in chain single }\end{array}$ & + & + & + & + & - & $\mathrm{A} / \mathrm{G}$ & Staphylococcus sp \\
\hline & & & + & - & - & - & + & $\mathrm{A} / \mathrm{G}$ & Streptococcus sp \\
\hline \multirow[t]{2}{*}{48} & $\begin{array}{l}\text { Raised, whitish, irregular, } \\
\text { round pinpoint }\end{array}$ & $\begin{array}{l}\text { Gram+, cocci, rod, } \\
\text { cluster in chain }\end{array}$ & + & - & + & - & - & $\mathrm{A} / \mathrm{G}$ & Leuconostoc sp \\
\hline & & & + & + & + & + & - & $\mathrm{A} / \mathrm{G}$ & Staphylococcus sp \\
\hline \multirow[t]{2}{*}{72} & $\begin{array}{l}\text { Raised, Pinpoint, irregular, } \\
\text { milky colonies }\end{array}$ & $\begin{array}{l}\text { Gram +ve rod cluster, } \\
\text { some in pairs. }\end{array}$ & + & - & + & - & - & $\mathrm{A} / \mathrm{G}$ & Bacillussp \\
\hline & & & + & - & + & + & - & $\mathrm{A} / \mathrm{G}$ & Lactobacillus sp \\
\hline \multirow[t]{2}{*}{96} & $\begin{array}{l}\text { Pinpoint, big, raised, } \\
\text { irregular light blue colonies }\end{array}$ & $\begin{array}{l}\text { Gram+, cocci in } \\
\text { cluster and chain }\end{array}$ & + & + & + & - & + & $\mathrm{A} / \mathrm{G}$ & Staphylococcus sp \\
\hline & & & + & - & + & - & - & $\mathrm{A} / \mathrm{G}$ & Bacillus sp \\
\hline \multirow[t]{2}{*}{144} & Flat, irregular, sticky colonies & $\begin{array}{l}\text { Gram+ rods,clusters } \\
\text { and pairs }\end{array}$ & + & - & + & + & - & $\mathrm{A} / \mathrm{G}$ & Bacillus sp \\
\hline & & & - & + & + & + & - & $\mathrm{A} / \mathrm{G}$ & Clostridium $\mathrm{sp}$ \\
\hline
\end{tabular}

Key: + =Positive, - = Negative, TSI= Triple sugar iron, A/G = Acid and Gas, sp. =species

\begin{tabular}{|c|c|c|c|c|c|c|c|c|c|}
\hline $\begin{array}{l}\text { Fermentation } \\
\text { period (hrs) }\end{array}$ & $\begin{array}{l}\text { Cultural } \\
\text { Appearance }\end{array}$ & $\begin{array}{l}\text { Gram } \\
\text { Reaction } \\
\end{array}$ & Catalase & Coagulase & Urease & Indole & Mortility & TSI & $\begin{array}{l}\text { Probable } \\
\text { Organism }\end{array}$ \\
\hline \multirow[t]{2}{*}{0} & $\begin{array}{l}\text { Raised, } \\
\text { irregular, milky } \\
\text { colonies }\end{array}$ & $\begin{array}{l}\text { Gram +ve, } \\
\text { cocci single } \\
\text { and chains }\end{array}$ & + & + & + & + & + & $\mathrm{A} / \mathrm{G}$ & $\begin{array}{l}\text { Staphylococcus } \\
\mathrm{sp}\end{array}$ \\
\hline & & & + & - & - & + & - & $\mathrm{A} / \mathrm{G}$ & Leuconostoc sp \\
\hline \multirow[t]{2}{*}{24} & $\begin{array}{l}\text { Flat, irregular, } \\
\text { sticky colonies }\end{array}$ & $\begin{array}{l}\text { Gram+ cocci, } \\
\text { rod, cluster } \\
\text { short chain }\end{array}$ & + & - & - & + & - & $\mathrm{A} / \mathrm{G}$ & Leuconostoc sp \\
\hline & & & + & - & + & + & - & $\mathrm{A} / \mathrm{G}$ & Lactobacillus sp \\
\hline 48 & $\begin{array}{l}\text { Flat, whitish, } \\
\text { sticky, round } \\
\text { colonies }\end{array}$ & $\begin{array}{l}\text { Gram } \\
\text { +vepairs } \\
\text { clusters in } \\
\text { chains }\end{array}$ & + & - & + & + & - & $\mathrm{A} / \mathrm{G}$ & Lactobacillus sp \\
\hline
\end{tabular}




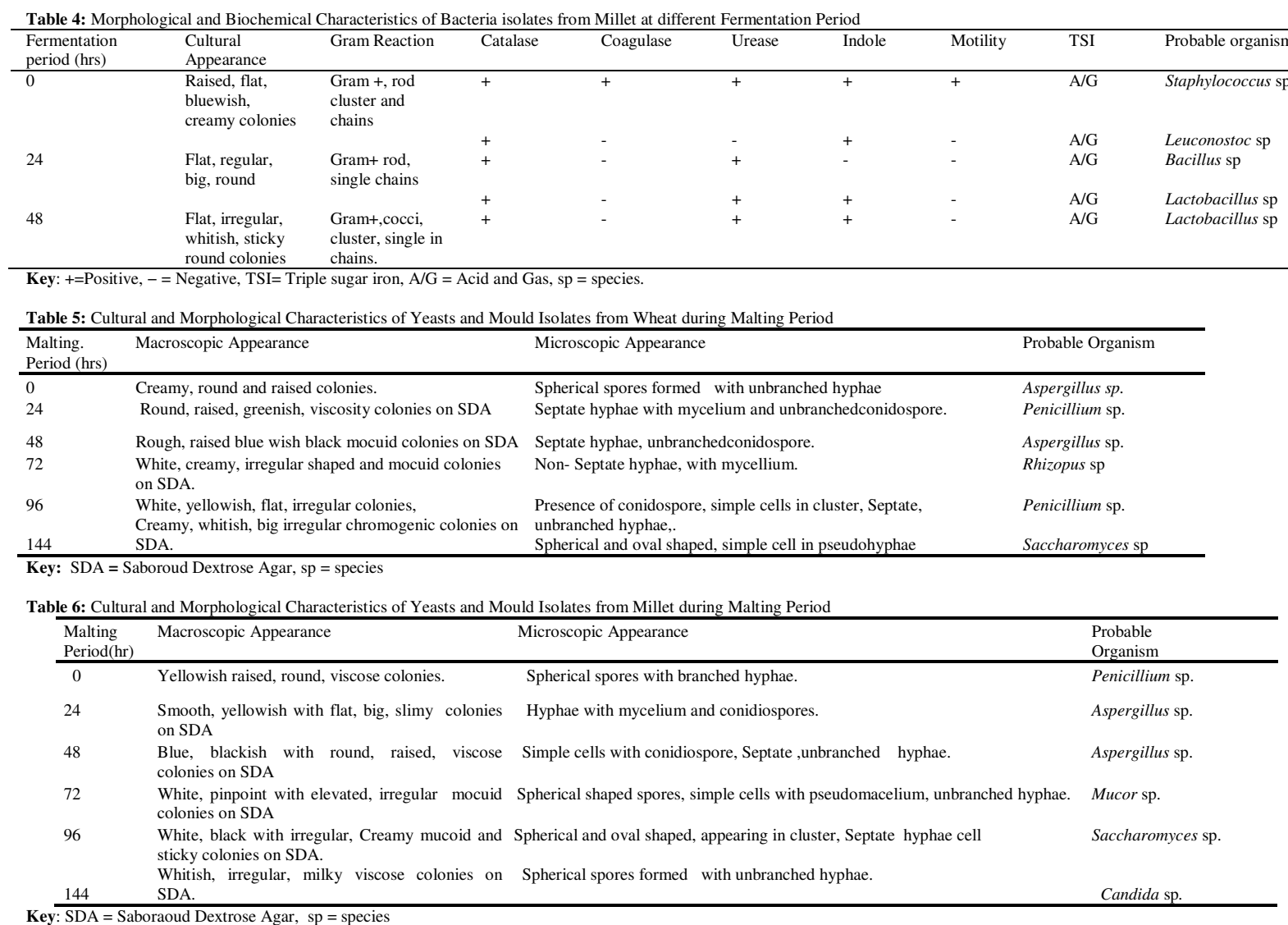

The microbial genera isolated at this phase are certain heat-resistant bacteria that were found present due to their ability to form spores, such as Bacillu ssp and fungi- Candida sp and some Saccharomyces sp continue to grow during the early hours of kilning. This is in agreement with the work of Douglas and Flannigan (2009) who worked on barley and wheat samples. Their organization in biofilms and spores may explain their high resistance to heat. The predominance of lactic acid bacteria during the fermentation period was confirmed. Fermentation influence viable microbes. The presences of Staphylococcus probably originated from the air, human handlers and other materials during fermentation and Leuconostoc sp, Lactobacillus sp. are predominance during the malting and are found to initiate fermentation as agreed by many authors on fermented cereal products (Opereet al., 2012) while working on millet and sorghum. Some LAB such as Lactobacillus sp is found to be dominant throughout the fermentation period, with decrease in $\mathrm{pH}$ below 4.0, while others are eliminated. This could be due to their ability to withstand low $\mathrm{pH}$ and other toxic organic acid produced as also reported by Opere $e$ al. (2012) on his work on sorghum. Previous workers have found several yeasts and mould in spontaneous lactic fermenting cereals including species of
Saccharomyces and Candida as well as Aspergillus sp (Jespersen, 2003). Their presence in fermented foods has been found to improve the aroma and flavor as reported by Adegbehingbe and Fakoya (2007) on his work on millet flour. The Saccharomyces sp was found to persist throughout the fermentation period in all the samples as similar with the work of Adegbehingbe and Fakoya (2007). The coexistence and symbiotic association between lactic acid bacteria and yeasts in fermented products have been reported by several authors (Omemuet al., 2007). Besides, LAB have been observed to be responsible for flavour development in fermented foods as in consistence with the finding of Omemuet al. (2007) who worked on sorghum. The molds (Penicilliumand Aspergillus) isolatedin wheat and millet during fermentation at the early stage of fermentation is commonly present as contaminants in cereals. Their sources could also be from the utensils, the processing water or others environmental factors as reported by Oyelana and Coker (2012) on their work on barley and sorghum. They further reported that LAB also contribute to the spoilage of fermented product. The total bacterial counts of processed wheat and millet indicate the level of microbial contamination. The bacteria and mould isolated in the processed cereals were the same as observed 
during the malting and fermentation period. And were found to play crucial role on malted and fermented product. Some are present as possible indication of contamination and health benefit as well, their source could be from environmental factor or due to low oxygen tension that result to their establishment as reported by Omemuet al. (2007) on his work on wheat and sorghum grains. The mean scores of sensory evaluation, which revealed that the formulated malted/fermented and fortified foods were liked very much compared with the unmalted/unfermented foods which are moderately and slightly liked. The panelist observed that malted/fermented blend food were more acceptable in terms of taste (8.5), flavor (5.4), colour (6.5) and texture (6.5) as compared to malted/fermented food product as similar to the report of Fapounda and Adeware (2012) who revealed that the statistical analysis of the overall acceptability showed significant differences from 7.5 for malted/fermented product and 8.5 for malted/fermented blend product

Table 7: Cultural and Morphological Characteristics of Yeasts and Mould Isolates from Wheat during Fermentation.

\begin{tabular}{lllc}
\hline $\begin{array}{l}\text { Fermentation } \\
\text { Period (hrs) }\end{array}$ & $\begin{array}{l}\text { Macroscopic } \\
\text { Appearance }\end{array}$ & Microscopic Appearance & Probable organisms \\
\hline 0 & $\begin{array}{l}\text { Raised, milky, Reddish } \\
\text { colonies }\end{array}$ & $\begin{array}{l}\text { Spherical and oval shaped, simple cells with } \\
\text { some appearing in conidiospores. } \\
\text { Non septate hyphae with cylindrical spores. }\end{array}$ & Candida sp. \\
48 & $\begin{array}{l}\text { Flat, pinpoint, whitish, } \\
\text { sticky colonies on SDA } \\
\text { Whitish, flat, moist colonies }\end{array}$ & Green conidia present with lemon-shaped. & Saccharomyces sp. \\
\hline
\end{tabular}

Key: SDA = Saboraud Dextrose Agar, $\mathrm{sp}=$ species

Table 8: Cultural and Morphological Characteristics of Yeasts and Mould Isolates from Millet during Fermentation

\begin{tabular}{|c|c|c|c|}
\hline $\begin{array}{l}\text { Fermentation. } \\
\text { Period (hours) }\end{array}$ & Macroscopic Appearance & Microscopic Appearance & Probable organism \\
\hline 0 & $\begin{array}{l}\text { Yellow, bluewish, raised, milky colonies } \\
\text { Blackish, creamy, flat with mucoid colonies }\end{array}$ & Branched hyphae forming mycellium. & Penicillium sp. \\
\hline 24 & $\begin{array}{l}\text { on SDA } \\
\text { Whitish, flat, smooth, round mucoid, } \\
\text { irregular colonies }\end{array}$ & $\begin{array}{l}\text { Cylindrical and oval shaped, simple cell with some } \\
\text { appearing } \\
\text { Cluster, septate, unbranched hyphae. } \\
\text { 'ylindrical spores shaped with conidia and } \\
\text { pseudohyphae. }\end{array}$ & $\begin{array}{l}\text { Saccharomyces sp. } \\
\text { Candida sp. }\end{array}$ \\
\hline
\end{tabular}

Key: SDA = Saboraoud Dextrose Agar, $\mathrm{sp}=$ species

Table 9: Cultural and Biochemical Characteristics of Bacteria Isolates from Processed Wheat and Millet

\begin{tabular}{llllllll} 
Samples Colonial Appearance & Gram reaction & Catalase & Coagulase & Urease & Indole Motility & TSI & Probable Organisms \\
\hline $\begin{array}{l}\text { Wheat Flat, whitish, small Gram+, rod, pairs } \\
\text { sticky round colonies,clusters in chains }\end{array}$ & + & - & + & + & - & A/G & Lactobacillus sp. \\
Millet Flat, irregular, whitish, Gram+, rod & + & - & - & + & - & A/G & Lactobacillus sp. \\
sticky round colonies,clusters, in chains.
\end{tabular}

Key: TSI $=$ Triple sugar,$+=$ Positive, $_{-}=$Negative, $\mathrm{A} / \mathrm{G}=$ Acid and gas, TSI $=$ Triple sugar iron, $\mathrm{sp}=$ species

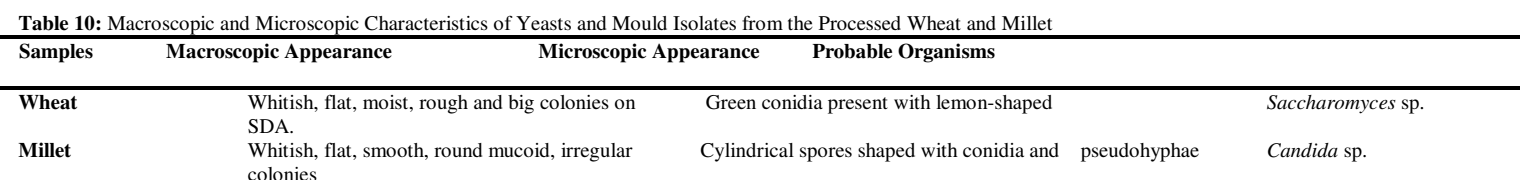

Key: SDA= Sabouraud dextrose agar, $\mathrm{sp}=$ species

Conclusion: In conclusion, the results from this research indicated that the use of locust beans as a fortifying agent can improved the protein contents and other nutritional value on the malted and fermented foods product. Therefore, this could be used to fortify or add nutrient to cereal foods and may be use in solving the problem of protein malnutrition. This observation could be advantageously utilized to improve nutrition of infant and children, particularly in developing countries, where wheat and millet is consumed in large quantities.

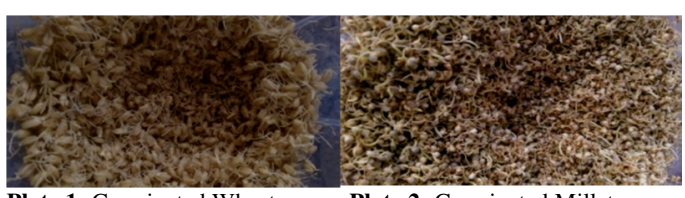

Plate 1: Germinated Wheat 


\section{REFERENCES}

Adeyemo, SO; Oloyode, O B; Odutua, AA (2003). Biochemical Analysis of Germinated and Fermented Cereals. Nutr. J. Sci. (6): 23-29.

Adegbehingbe, K T; Fakoya, S. (2007). Fermentation of 'ogwo' using Starter Cultures. J.Appl. Environ. Sci. 3(2): 137-142.

Ackermann, A (2008). Mycoflora of South African Cereals and Malt.J. Americ. Soc. Brew. Chem.56,169- 176.

Ariahu, C;Ukpabi, U; Mbagunwa, K (2009). Production of African Breadfruit (Treculia African) and soyabeans (Glycine max) seed base formulation; Effect of Germination and Fermentation on Nutritional and Organoleptic Quality. Pla. F. Hum Nutr., J., 54:126-266.

Association of Official Analytical Chemists, AOAC (2005): Official methods of Analysis.18th Edition. Association of Official Analytical chemists, Washington, D.C, USA.

Bender, DA; Bender, A (2009). Benders'Dictionary of Nutrition and Food Technology, 7th ed. Woodhead Publishing,

Abington.p 65-67.

Brigas, DE; Hough, R; Young,TN (2003).Malting and Brewing Science Malt and Sweet wort. $2^{\text {nd }}$ Edn.Chapman and Hall, UK.p.295-296.

British Nutrition Foundation, BNF,(2004). Starchy Foods in the Diet. BNF, London. MCsongs. Ltd.p13-56

Cheesbrough, M (2009). DistrictLaboratory Practice in Tropical Countries, Part 1. Publish by Cambridge University Press. ISBN 10: 052167304.

Douglas, P; Flannigan, B (2009).Microbiological Evaluation of Cereal Malt Production.J. Inst. Brew.94: 85-88.

Fapounda, SO; Adeware, A (2012). Microbial Load Keeping Quality of Kunun under various Preservative Regimes. J. Nutr. F. Sci. 2: 141 .

Haikara, A;Mäkinen, V; Hakulinen, R (2002). The microflora of barley after harvesting, during storage and malting.Proceedings of the European Brewery Convention Congress, Amsterdam. Oxford, UK: IRL Press p. 35-46.

Jespersen, L (2003). Occurrence and taxonomical characteristics of strains of Saccharomyces cerevisiae predominant in African indigenous fermented foods and beverages.FEMS Yeasts Res.3:191-200.

Kent, NL; Evers, AD (2004). Kent's Technology of Cereals, 4th edn. Elsevier, Oxford.

Laitila, A (2007). Microbes in the tailoring of barley malt properties, $\mathrm{PhD}$ thesis, University of Helsinki and VTT Technical Research Centre of Finland, p. 107.

Lowe, DP;Arendt, EK (2004). The use and effects of lactic acid bacteria in malting and brewing with their relationships to antifungal activity, mycotoxins and gushing: a review, J. Inst. Brew. $110: 163-180$.

Mbata, TI; Ikenebomeh, MJ; Alaneme, JC (2009). Studies on the microbiological, nutrient composition and antinutritiona contents of fermented maize flour fortified with bambara groundnut (Vigna subterranean L). Afric. J. F. Sci. 3(6): $165-171$.

Macrae, R., Robinson, R. K, and Sadler, M. J.(2006). Encyclopaedia of Food Science, Food Technology and Nutrition. Academic Press, London.

Nicholas, A; Bokulich, AB; Charles, WB (2013).The Microbiology of Malting and Brewing.Microbiol. Mol. Biol. Rev. 77 (2): 157-172.

Noots, I; Delcour, JA; Michaels, CW(2008). From field barley to malt: detection and specification of microbial activity for quality aspects, Critic. Rev.Microbiol.25:.121-153.

.Obadina, AO; Oyewole, OB. Awojobi, TM (2008).Effect of steeping time of milled grains on the quality of KunuZaki (A Nigeria Beverage).Afric. J. F. Sci. 3(2): 035 - 036.

Omemu, AM (2007). Fermentation dynamics during production of $o g i$, a Nigerian fermented cereal porridge. Rep. Opin. 3(4): 8-17.

Opere, B.; Aboaba, EO; Ugoji, OO; Iwalokun, BA (2012).Estimation of Nutritive Value, Organoleptic Properties and Consumer Acceptability of Fermented Cereal Gruel (OGI).Adv. J. F. Sci. Technol. 4(1): 1-8.

Osman, MA (2007). Effect of different processing methods on nutrient composition, antinutritional factors an in vitro protein digestibility of Dolichos lablab bean (Lablab purpuresus(L) Sweet). Pak. J.Nutr. 6: 299-303.

Oyelana, OA; Coker, AA (2012). Microbial contamination at different stages of production of 
ogi in Mowe: a rural area community, Southwest, Nigeria. Bacteriol. J. 2(1): 1-11.

Oyeleke, S.B. and Manga, B.S. (2008).Essentials of Laboratory Practicals in Microbiology (first edition), Tobest publishers.Minna, Nigeria, p. 2862 .

Petters, HI.; Flannigan, B; Austin, B (2008). Quantitative and qualitative studies of the microflora of barley malt production, J. Appl. Bacteriol.65:279-297.

Raulio, M.; Wilhelmson, A; Salkinoja-Salonen, M; Laitila, A (2009). Ultrastructure of biofilms formed on barley kernels during malting with and without starter culture. F. Microbiol., 26: 437-443.

Schwarz, PB; Casper, HH; Beattie, S (2005).Fate and development of naturally occurring
Fusariummycotoxins during malting and brewing, J. Americ.Soc. Brew. Chem. 53: 121-127.

Steinkrous, KH (2003). Classification of Fermented Foods.Worldwide Rev. of Household Ferm. Tech. F.Contr. 8:311-317.

Sullivan, T; Walsh, Y; O’Mahony, A; Fitzgerald, G; Van Sinderen, D (2000). A comparative study of malthouse and brewhousemicroflora.J. Inst.Brew. 105: 55-61

Uvere, P.O; Onyekwere, EU; Ngoddy, PO (2010). Production of maize-bambara groundnut complementary foods fortified pre-fermentation with processed foods rich in calcium, iron, zinc and provitamin A. J. Sci. F. Agric. 90: 566-573.

Willett, W; Manson, JA; Liu, S (2003).Glycemic index, glycemic load, and risk of type 2 diabetes.Americ. J. Clin. Nutr.76: 74S-80S. 